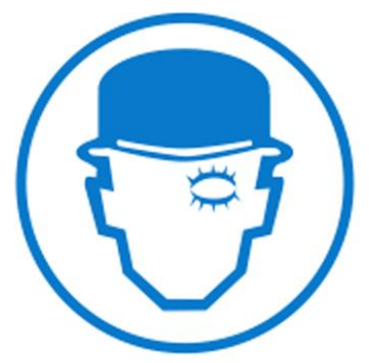

REVISTA TRANSGRESSÕES: CIÊNCIAS CRIMINAIS EM

DEBATE, V.5, N.2, MAIO DE 2017

LIZ VIEIRA MACHADO

UNIVERSIDADE FEIDERAL DO SERGIPE

EMAIL: lizvieiram@gmail.com

\title{
Bandido não é homem de bem
}

Homem de bem não é bandido

Bandido não é homem de bem

Bandido rouba, estupra, mata

Homem de bem...também

Mas homem de bem não é bandido

Porque para ser bandido

Tem que parecer bandidoso

É por isso que tem homem que é bandido

E tem homem que é bondoso

Bondade quer fazer o que der na telha

Amarra, bate, decepa-lhe a orelha

“Ah, então vá! Adote um vagabundo!"

Só se eu for adotar todo mundo

"A ignorância é doce"

Vagabunda, antes fosse 